University of Tulsa College of Law

TU Law Digital Commons

Articles, Chapters in Books and Other Contributions to Scholarly Works

2008

Foundations of Baghdad's Argument that Regions Lack Constitutional Authority Over Oil and Gas Development Agreements

Rex Zedalis

Follow this and additional works at: http://digitalcommons.law.utulsa.edu/fac_pub

Part of the Law Commons

Recommended Citation

26 Intl Bar Assoc.'s J. Energy \& Nat. Res. L 303 (2008).

This Article is brought to you for free and open access by TU Law Digital Commons. It has been accepted for inclusion in Articles, Chapters in Books and Other Contributions to Scholarly Works by an authorized administrator of TU Law Digital Commons. For more information, please contact daniel-bell@utulsa.edu. 


\title{
COMMENT
}

\section{Foundations of Baghdad's Argument that Regions Lack Constitutional Authority Over Oil and Gas Development Agreements}

\author{
By Rex J Zedalis*
}

Iraq's oil wealth is well known. In recent months, the failure of that nation's legislature to adopt a national oil law, and the interest of a variety of smaller and mid-sized international oil companies in exploiting the oil riches of the more stabile Kurdish Region, have combined to result in the Kurdish Regional Government striking oil development agreements with roughly a dozen separate entities. The legal validity of these agreements may be questioned under the terms of the Iraqi Constitution. In what follows, an effort is made to detail the most persuasive and forceful legal arguments that could be proffered by the central government to counter claims of regional governments possessing constitutional authority to enter into development agreements like those negotiated by the Kurds. In short, these arguments are based on the notion of the Constitution not assigning control over oil and gas activity to sub-central governmental entities. 
The failure of the Iraqi federal legislature to adopt a national hydrocarbons law, ${ }^{1}$ and the recent news reports about several exploration and development agreements negotiated between the Kurdistan Regional Government (KRG) and officials of international oil companies such as Norway's DNO, Britain's Sterling Energy and America's Hunt Oil, ${ }^{2}$ suggest the need to articulate the legal basis for Baghdad's view that the agreements exceed the powers provided to regional governmental units by the terms of the Iraqi Constitution. ${ }^{3}$ The author

* Rex J Zedalis is Professor of Law and Director, Comparative and International Law Center, and Fellow, National Energy-Environment Law and Policy Institute, University of Tulsa; W B Cutting Fellow in International Law (1980-81) and JSD (1987), Columbia University. He can be contacted by e-mail at rex-zedalis@utulsa.edu. The author would like to express his appreciation to R Dobie Langenkamp, former Professor of Law and Director, National Energy-Environment Law \& Policy Institute, University of Tulsa, and consultant to the US Department of Energy on Iraqi oil and gas law matters, for his invaluable discussions, comments and insights. The views herein represent those of the author and not those of Professor Langenkamp or the US Government.

1 See 'Official says Iraqi oil talks deadlocked', Iraq Updates (14 September 2007), available at www.iraqupdates.com/p_articles.php/article21766 (accessed 17 October 2007); 'A vital oil law for Iraqis', Iraq Updates (17 September 2007), available at www. iraqupdates.com/p_articles.php/article21846 (accessed 17 October 2007); 'The rise and fall of Iraq's oil law', Iraq Updates (21 September 2007), available at www.iraqupdates.com/p_articles.php/article22008 (accessed 17 October 2007); 'Parliament delays voting on law', Iraq Updates (9 October 2007), available at www.iraqupdates.com/ p_articles.php/article22671 (accessed 17 October 2007); 'Deputy PM says Iraq some way off oil agreement', Iraq Updates (18 October 2007), available at www.iraqupdates. com/p_articles.php/article22976 (accessed 19 October 2007).

2 On these three specific contracts see 'DNO sees no threat to Kurdistan oil deal', Iraq Updates (19 November 2006), available at www.iraqupdates.com/p_articles.php/article11920 (accessed 28 December 2006); 'Sterling eyes Kurdish deals', Iraq Updates (20 August 2007), available at www.iraqupdates.com/p_articles.php/article20837 (accessed 3 October 2007); 'Texas oil company signs deal with Kurdistan government', Iraq Updates (10 September 2007), available at www.iraqupdates.com/p_articles.php/article21523 (accessed 30 September 2007). For deals with companies such as Turkey's Genel Energi, Switzerland's Addax, and the UAE's Dana Gas see generally, 'Genel Energi and Addax Petroleum announce the execution of a revised production sharing agreement in respect to the Taq Taq field', Iraq Updates (23 November 2006), available at www.iraqupdates. com/p_articles.php/article12038 (accessed 28 December 2006); 'Dana Gas, Kurdish PSA plan', Iraq Updates (23 April 2007), available at www.iraqupdates.com/p_articles. php/article16717 (accessed 3 May 2007). Iraq Updates, available at www.iraqupdates.com provides excellent coverage of these and other KRG deals.

3 See 'New Iraqi Kurdish oil law may trigger confrontation with Baghdad, won't attract leading oil companies', Iraq Updates (14 August 2007), available at www.iraqupdates. com/P_articles.php/article20620 (accessed 1 September 2007); 'Iraqi oil minister says Hunt Oil deal with Kurd regional government illegal', Iraq Updates (11 September 2007), available at www.iraqupdates.com/p_articles.php/article21638 (accessed 14 September 2007). For the Kurds' defence of the contracts, see 'KRG responds to Dr Shahristani's recent statements on oil', Iraq Updates (12 September 2007), available at www.iraqupdates.com/p_articles.php/article21660 (accessed 14 September 2007); 'Iraq's Kurdish administration wants oil minister sacked', Iraq Updates (17 September 2007), available at www.iraqupdates.com/p_articles.php/article21837 (accessed 1 October 2007); 'Iraq's Kurdistan defends oil deals', Iraq Updates (9 October 2007), available at www.iraqupdates.com/p_articles.php/article22691 (accessed 15 October 2007). 
has argued elsewhere that regional governments possess the constitutional authority independently to enter into agreements like those struck by the KRG. ${ }^{4}$ Without equivocating on or changing positions regarding this matter, the author is prepared to acknowledge that the many ambiguities and broadly drafted provisions of the Iraqi Constitution leave room for contending that regional authority is far from crystal clear. For this and other reasons, it seems important to set out the specifics of the strongest legal argument that might support the position that the Constitution does not grant regional units the necessary power to enter into oil development agreements.

In what follows, that particular objective will be approached by first describing for the reader the overall structure of the Iraqi Constitution and the essence of its relevant provisions. Thereafter, both the general and the specific powers assigned to the federal government and implicating oil development agreements will be examined. Subsequently, reference will be made to the significance of the relationship between those constitutional powers assigned exclusively to the federal government, those designated by the Constitution as shared, and those left to be exercised as mere collaborative powers. This brief commentary's final substantive section then takes up the effect of the constitutional language declaring oil and gas a resource held by all the peoples of Iraq.

Two things should be kept in mind when approaching the arguments, evaluations and ideas reflected herein. For openers, the analysis of the constitutional provisions examined proceeds without the benefit of the kind of exhaustive, official negotiating record available on the constitutions of some other nations. As is well-known, the Iraqi Constitution was the product of substantial political compromise between ethnic factions and religious persuasions, all willing to give on some issues and not on others in order to secure self-governance and portray to the international community at least the semblance of national progress and stability. Absent, however, is any comprehensive, authoritative and formal negotiating record that would inform the meaning of unclear constitutional provisions to any greater extent than the very language of the provisions themselves. The other thing to keep in mind goes without saying and concerns the fact that the mode of reasoning by which the analysis proceeds tracks the traditional approach of systematic, deductive, rational argumentation. It is certainly possible some may find fault with this approach, suggesting instead that, when dealing with constitutions that emerge out of distinctive cultures with unique methods of analysis and inquiry resolution, the interpretive approach should reflect the culture itself. The legitimacy of such an observation cannot be denied, but

4 Rex J Zedalis, 'Recent Oil Contracts With Kurdish Authorities: Are They Legally Valid?' Int'l Energy $L$ E' Taxation Rev (forthcoming 2008). 
unfortunately the author's training and knowledge confine the analytical framework to that familiar to practitioners of the common and the civil law traditions of European countries.

\section{A primer on the structure and relevant provisions of the Constitution}

The provisions of the Iraqi Constitution ${ }^{5}$ relevant to the question of regional authority independently to enter into oil development agreements fall into four basic categories. In an effort simply to provide contextual orientation, not interpretive conclusions, it may prove of some value succinctly to describe the essence of those categories and set them into the overall structure of the Iraqi Constitution.

The first category of relevance is captured by the language of Article 110. It sets out a moderately lengthy list of powers that are exclusive to the federal government. ${ }^{6}$ These powers can neither be claimed nor exercised by the regions or governorates in Iraq. Though a variety of important powers are provided as exercisable by the federal government alone, those most apposite to oil development agreements include the powers over formulating foreign 'economic and trade policy', and 'regulating commercial policy' ${ }^{7}$ Obviously, the powers mentioned are general, and do not relate solely to the matter of oil development agreements.

The second category is captured in Article 114. ${ }^{8}$ This Article provides for the powers that the federal government must share with the regions. Again, as with Article 110, many powers not at all associated with oil development agreements are listed. One that could play a role in that respect, however, is the power to formulate 'development and general planning policies'. ${ }^{9}$ But even here, Article 114 simply provides for a power that, again, is extremely broad and capable of applying to far more than agreements concerning oil exploration and development. It is also worth re-emphasising that all the powers referenced in Article 114 are powers shared between the federal government and the regions, not powers exclusive to the regions themselves.

The third category recognises that the combined effect of Articles 110 and 114 fails to exhaust all possible powers that governments, whether federal or sub-central, may wish to exercise. As a consequence, the Constitution then

5 See Iraqi Constitution, available at www.export.gov/iraq/pdf/iraqi_constitution.pdf (accessed 11 October 2007).

6 See ibid at Art 110.

7 See ibid at Art 110, First and Third.

8 See ibid at Art 114.

9 See ibid at Art 114, Fourth. 
sets about to assure that all such residual powers are assigned. In addressing that task, Article 115's first sentence provides: 'All powers not stipulated in the exclusive powers of the federal government belong to the authorities of the regions and governorates that are not organized in a region. ${ }^{10}$ In light of the fact neither Article 110 nor 114 explicitly speaks to power over matters involving oil and gas, it would make sense to think of Article 115's reservation as doing so indirectly. However, account must still be taken of Article 112."

Article 112 represents one of the provisions that comprises the fourth category of relevance. It speaks directly and explicitly to the matter of oil and gas by way of two provisions. In the opening one, Article 112, First, it provides that the federal government, not on its own but in collaboration with the regions and governorates, has power over the 'management' of oil and gas. ${ }^{12}$ This power relates to oil and gas extracted from so-called 'present' oil and gas fields. ${ }^{13}$ The exact language of that provision states that: '[ $\left.\mathbf{t}\right]$ he federal government, with the producing governorates and regional governments, shall undertake the management of oil and gas extracted from present fields ... . ${ }^{14}$ In the other provision, Article 112, Second, the federal government is provided with the additional collaborative authority to undertake the formulation of 'strategic policies' for developing oil and gas resources generally. ${ }^{15}$ In contradistinction to Article 112, First's, assignment over dayto-day 'management' operations of oil and gas fields, ${ }^{16}$ the Constitution's

10 See ibid at Art 115. Article 115's second sentence is also interesting and important in situations where powers 'shared' between federal and sub-central authorities conflict with each other. That sentence reads: 'With regard to other powers shared between the federal government and the regional governments, priority shall be given to the law of the regions and governorates not organized in a region in case of dispute.'

11 See ibid at Art 112.

12 See $i b i d$.

13 See ibid at Art 112, First.

14 See $i b i d$. The balance of Art 112, First, is also of importance. Immediately following its indication that the federal government, with the producing governorates and regional governments, are to undertake the management of oil and gas extracted from present fields, it declares the condition: "provided that it distributes its revenues in a fair manner in proportion to the population distribution in all parts of the country, specifying an allotment for a specified period for the damaged regions which were unjustly deprived of them by the former regime, and the regions that were damaged afterwards in a way that ensures balanced development in different areas of the country, and this shall be regulated by law.'

15 See ibid at Art 112, Second. The precise language of Art 112, Second, reads: 'The federal government, with the producing regional and governorate governments, shall together formulate the necessary strategic policies to develop the oil and gas wealth in a way that achieves the highest benefit to the Iraqi people using the most advanced techniques of the market principles and encouraging investment.'

16 See ibid at Art 112, First. 
assignment in Article 112, Second, of the power to formulate strategic policy for developing those resources, is both broad-ranging and forward looking. That is to say, it is concerned with the creation of plans to bring about the most productive use of Iraq's oil and gas resources, not just the oversight and rationality of current activities related to actual practices in the field.

The other constitutional provision represented in the fourth category is Article 111. ${ }^{17}$ As with Article 112, Article 111 also deals very explicitly and directly with oil and gas. In contradistinction to Article 112, however, it contains a single legal principle, one that is significantly more general in nature. As noted, Article 112's two paragraphs address the management of oil and gas extracted from present fields, and the creation of strategic policies for the overall development of Iraq's oil and gas resources. Article 111, on the other hand, provides simply that Iraq's oil and gas resources are owned by all the people of Iraq. ${ }^{18}$ Though not explicitly alluding to allocations of constitutional power between the federal and sub-central governmental units, its declaration that the nation's oil and gas resources belong to the Iraqi people is not entirely inconsequential.

From the combination of these provisions, it is easy to understand how one could arrive at the conclusion expressed elsewhere by the author that it is each of the regional governmental units in Iraq, and not the federal government in Baghdad, that is vested with the constitutional authority to enter oil development agreements similar to those negotiated by the KRG. ${ }^{19}$ After all, Article 110, which lists the powers exclusive to the federal government, makes no mention of such authority, and Article 114, which lists the powers to be shared with the regions, finds itself in a comparable situation. Article 112 does speak to oil and gas, but is limited in its reach to 'management' of 'present fields', and 'strategic [development] policies' concerning oil and gas generally. The result is to place reliance on both Article 115's reference to residual powers, all of which remain in the regions and governorates, and its reference to sub-central power 'trumping' inconsistent federal measures whenever power is to be shared between the federal government and the sub-central units. ${ }^{20}$ However, despite the attractiveness of the conclusion that regional governments possess the constitutional power to strike the kinds of oil development agreements entered into by the KRG, several solid legal arguments exist in favour of the view that only the federal government is

17 See ibid at Art 111.

18 See $i b i d$ (referencing the fact that that includes the people 'in all the regions and governorates').

19 See $n 4$ above.

20 See ibid at Art 115, second sentence, quoted in $\mathbf{n} 10$ above. 
vested with such power. ${ }^{21}$ In large measure, as revealed below, these arguments emphasise the reach of some of the general powers assigned exclusively to the federal government by Article 110, the lead role to be played by federal authorities under Article 112's specific powers over managing present oil and gas fields, and formulating 'strategic policies' for developing any and all oil and gas fields, and the declaration in Article 111 that Iraq's oil and gas resources are owned by all the peoples of that nation.

\section{Articles 110 and 112: the general powers over both 'economic and trade policy' and 'commercial policy', and the specific powers over oil and gas 'management' and 'strategic [development] policies'}

The general powers over economic and trade policy, as well as commercial policy, that are assigned exclusively to the federal government by Article 110 can be viewed as envisioning no room for sub-central governmental units independently to enter into oil development agreements. Clearly, oil and gas activity anywhere within the territory of Iraq has ramifications for the nation's economic policy. Every decision to facilitate or not the exploration for and exploitation of oil and gas sends ripples through the economy, thereby having an impact on policy regarding the economy. And given that such hydrocarbons are produced neither for the mere sake of production, nor for domestic consumption alone, their sale for export on to the international market has consequences for trade policy as well. In light of this, would it not make sense for one to think that the act of negotiating, structuring and finalising an oil development agreement would impinge on powers assigned exclusively to the federal government?

Likewise with respect to Article 110's federal government power over commercial policy; surely that assignment of exclusive constitutional authority encompasses all things involving commercial transactions. By

21 There have been few detailed analyses of the question of constitutional authority to enter oil development agreements. For a brief analysis arguing the power is assigned to the federal government, see Memorandum, Joseph C Bell and Professor Cheryl Saunders, Iraqi Oil Policy - Constitutional Issues Regarding Federal and Regional Authority (7 July 2006), available at www.iraqrevenuewatch.org/reports/MEMORANDUMCons titutional\%20Interpretation.DOC (accessed 15 October 2007). See also Tariq Shafiq, 'Kurdistan Regional Government Hydrocarbon Law: A Commentary', 49 Middle East Economic Survey (No 37) (18 September 2006), available at www.mees.com/postedarticles/oped/v49n38-5OD0.htm (accessed 15 October 2007). Leaving open the door that regional governments possess at least limited power to enter into oil development agreements, see Haider Ala Hamoudi, 'The Hunt Oil Dispute and the Future of Iraqi Federalism', JURIST: Legal News \& Research (9 October 2007), available at http://jurist.law.pitt.edu/forumy/2007/09/hunt-oil-dispute-and-future-of-iraqi.php (accessed 12 October 2007). 
vesting the federal government in Baghdad with the sole power to regulate commercial policy, the drafters of the Constitution must have anticipated that the terms and provisions of all contractual arrangements, including those looking towards the development of oil and gas resources, would have to comply with requirements established by federal statutory or regulatory standards. In other words, if sub-central governmental units were acknowledged as possessing constitutional power autonomously to strike international oil development agreements - indisputably a form of commercial contract - would that not mean Article 110's assignment to the federal government of exclusive power over the regulation of commercial policy could be seriously undercut? Accepting this as so, it would certainly seem to make sense to read the Constitution's assignment of power over commercial policy exclusively to the federal government as a rejection of the notion that regional authorities have the power to negotiate, structure and finalise oil development agreements.

To the extent one may be reluctant to place too much weight on Article 110's assignment of more general powers, it is obvious that Article 112's specific powers connected with oil and gas buttress the claim that, at least with regard to so-called 'present fields', ${ }^{22}$ striking oil development agreements is the sole province of federal governmental authorities. This emerges from the fact that Article 112, First, provides that the 'federal government, with the producing governorates and regional governments', is to undertake the 'management' of oil and gas extracted from present fields. ${ }^{23}$ As with Article 110 's assignment to the federal government of power regarding foreign economic and trade policy, as well as overall commercial policy, Article 112, First's, grant to the federal government, albeit in collaboration with subcentral units, of the power over the management of present fields suggests superior authority at the level of the central government in Baghdad. True, the federal government is not entitled to exercise a management authority over present fields that ignores or disregards the input of the sub-central units. While management must be collaborative, the very language of Article 112 makes clear that it is the federal government that is to take the lead role. The implication is that, in the event of disagreement, it is the desires of the federal government that are to be preferred. Further, in executing the

22 See text accompanying $n 13$ above.

23 See Iraqi Constitution, n 5 above, at Art 112, First. It cannot be stressed strongly enough that the management authority over present fields is not unconditionally assigned to the federal government, with the sub-central governmental units. Article 112, First, contains a proviso that conditions the management authority. The proviso is constructed around the obligation of the federal government to meet specific revenue distribution obligations, obligations that look towards a fair and equitable distribution of all revenues throughout the country. 
collaborative role, the functions of the federal government are to concern the actual task of oil and gas management. And, just as Article 110's exclusive federal powers over economic, trade and commercial policy can serve to obstruct regional claims to a right to enter into oil development agreements, so Article 112, First's, authority over management can have the same effect. After all, how is it possible for federal officials effectively to manage oil and gas in present fields, if the various sub-central units are entitled independently to strike international oil development agreements?

The grant of power in Article 112, Second, concerning 'strategic [development] policies' for oil and gas is not limited to present fields. ${ }^{24}$ In this important respect, it differs from the first paragraph of that Article. Nonetheless, in reiteration of the notion that the federal government is to take the lead role in collaboratively formulating strategic development policies regarding oil and gas, it parallels Article 112's just discussed management provision. Along that same line, the reference in Article 112, Second, to 'strategic [development] policies' is plainly broad enough to bring within its reach as many sorts of practices and transactions as are caught both by the other relevant grants of power exclusive to the federal government in Article 110, and by the oil and gas management function concerning which the federal government is to take the lead role in collaborating with subcentral units. By its very nature, oil and gas strategic development policies are affected every time a development agreement to explore for and exploit oil and gas is struck. Strategic development policies outline plans regarding the production of such resources, and development agreements necessarily have an impact on the implementation of those policies. Thus, there is little reason to believe that the drafters of the Constitution, in assigning the federal government the lead role in collaborating on the creation of strategic development policies concerning oil and gas resources, envisioned the sub-central units being vested with constitutional authority to enter into international contracts regarding such. Presumably, the power to do so was viewed as implicitly vested in federal authorities alone.

\section{Significance of the second sentence of Article 115}

As noted earlier, Article 115 of the Iraqi Constitution provides that powers not assigned exclusively to the federal government are retained by the subcentral units. ${ }^{25}$ Essentially, this means powers not granted to the federal government by Article 110 remain in the regions and governorates. The

24 See ibid at Art 112, Second.

25 See text accompanying $\mathrm{n} 10$ above. 
second sentence of Article 115 provides, as also seen, that sub-central power 'trumps' inconsistent exercises of federal power in those areas where the federal and sub-central authorities have shared powers. The interesting question thus present has to do with possible conflicts arising from regional authorities entering in to oil development agreements that federal authorities argue are inconsistent with either the grant to federal authorities under Article 112, First, of management powers concerning present fields, or the parallel grant under Article 112, Second, of powers concerning strategic development policies regarding all oil and gas fields.

In closely reading the second sentence of Article 115, it is clear that its scope is limited to conflicts arising from constitutional powers designated as 'shared'. There can be no doubt this extends to all those powers listed in Article 114; powers that the federal government cannot exercise exclusively, but in which the federal government must allow the regional governmental units to participate. While it is arguable that Article 112's powers over management of present fields, and the formulation of strategic development policies associated with oil and gas resources, are to be shared between federal authorities and the sub-central units, the distinction between Article 110's exclusive powers, Article 114's shared powers and Article 112's collaborative powers cannot be ignored. Article 112's powers are neither exclusive to the federal government, nor shared with the regions in the sense in which Article 114 utilises that term. As it seems more appropriate to describe the management and strategic development policies powers of Article 112 as being somewhat less than exclusively federal, and more than simply shared, Article 115's second sentence would not apply in the event of a conflict between the desires of the federal government and those of a sub-central unit regarding an international oil development agreement. Stated differently, the ability of sub-central desires to trump inconsistent desires of the federal government reaches not farther than to those instances in which the two governmental bodies exercise their Article 114 shared powers. It does not affect situations in which the federal government relies on its Article 112 lead, collaborative role over the management of present fields or the creation of strategic development policies concerning oil and gas resources.

Obviously, when it comes to situations involving federal government invocation of an exclusive power over economic, trade, or commercial policy under Article 110, absolutely no possibility exists of sub-central units trumping federal desires. The specific range of the second sentence of Article 115 does not extend beyond conflicts in the shared power realm. And while one might mistakenly regard Article 112's collaborative powers as shared, there is no possibility of Article 110's powers being looked on in 
that same light. In the event sub-central authorities were to contend that independently hammered-out international oil development agreements somehow take priority over federal governmental desires to abstain from such, it would seem incontrovertible that exclusive federal power regarding foreign economic and trade policy, as well as general commercial policy, would be left unaffected by Article 115 .

\section{Article 111: oil and gas owned by all Iraqis}

From what we have seen, Article 112 contains important powers regarding oil and gas management and strategic development policies. These powers are to be exercised by the federal government, with the sub-central units. Admittedly, the power concerning management is limited to present oil and gas fields, but within that realm the very notion of management would seem extensive enough to crowd out any right of regions independently to enter into oil development agreements, and the additional power regarding strategic development policies would seem to have the same effect. Coupling these powers, specific to oil and gas, with the Article 110 more general powers exclusive to the federal government, leaves little room for acknowledging anything other than that it is the federal government in Baghdad that has the constitutional authority for striking international oil development agreements.

Article 114 does reference a shared power concerning 'development and general planning policies'. And, conceivably, it might be suggested that this power entitles governmental entities other than the federal government to negotiate, structure and finalise oil development agreements. The power specified in Article 114, however, is nothing more than a power of the federal government that must be shared with the regions. It is not a power the regions are entitled to exercise alone. While in the event of a conflict between the federal government's desires concerning that power and those of the regions, the trumping provision of Article 115's second sentence would give preference to the regions. It is unlikely, especially given the broad nature of the exclusive powers assigned to the federal government by Article 110, and its powers related specifically to oil and gas under Article 112, that, in defence of a claim of sole federal authority over oil development agreements, reliance would be placed on a shared power contained in Article 114.

The other provision of the Iraqi Constitution supporting the federal government's authority over international agreements regarding the exploration for and exploitation of the nation's oil and gas resources is 
Article 111. That provision is crystal clear in expressing the fundamental principle that the oil and gas resources of Iraq belong to the Iraqi people. The specific language reads: 'Oil and gas are owned by all the people of Iraq in all the regions and governorates.' 26

Though it might be possible for one to suggest this provision grants each Iraqi citizen a discrete and legally recognised property interest in the nation's oil and gas resources, the practical difficulties that would then be faced by private companies interested in securing contracts to exploit resources in which so many individuals held identifiable rights would seem to militate against attributing such a reading to that provision. In short, such a reading would render Article 111 unworkable. Given this reality, the explicit, unambiguous and direct nature of the principle set out in Article 111 would seem best read as indicating that the Constitution vests in the federal government the power to contract in connection with the nation's oil and gas resources. While it may come to pass that sub-central governmental units in Iraq admirably perform the task of servicing the peoples of their regions and governorates, it is the federal government in Baghdad that gives full effect to the notion of representing and acting for all the peoples of all the regions and governorates. The federal government mirrors, in a rough sense, the ethnic, religious, ideological, regional and tribal elements present in the nation as a whole. In view of this, why should anyone conclude anything but that Article 111 emphasises the point the federal government alone has the power to contract regarding the nation's oil and gas resources? As the sole representative of all Iraq's peoples, the federal government is the entity entitled to take the actions which transform into legal measures the significance of the Article in the Constitution's declaration that all Iraqis own the nation's oil and gas resources.

Were the position to be taken that Article 111 somehow vests regional governments with that power, there would be little question that the governments of the sub-central units with physical control over oil and gas resources would be likely to give an entirely different meaning to that provision. The inclination to engage in exploitation for the economic advantage of their populations alone would be irresistible. However, two problems exist which seem to foreclose reading Article 111's reference as assigning to any unit other than the federal governmental unit the power to give full and complete effect to ownership. First, it is clear that not all the sub-central units with oil and gas resources have entirely homogeneous ethnic and religious groupings. And secondly, it is equally as clear that, even among the regions of the country in which a certain ethnic or religious

26 See text accompanying $\mathbf{n} 17$ above. 
group predominates, nature itself has seen fit to provide far less than a fair or proportionate distribution of oil and gas resources. As a consequence of these two problems, it certainly appears the intent of Article 111 was to leave absolutely no confusion about the fact that the federal government in Baghdad, a government representative of all the rival ethnic, religious, ideological, regional and tribal groupings in the country, is the official unit vested with the constitutional power to give meaningful and practical effect to the declaration that the nation's oil and gas resources are owned by all the Iraqi people. Leaving implementation of that provision to the sub-central authorities would allow each region of the country blessed with oil and gas to deny the benefits to either those regions less well endowed, or even minority populations within their own region. By interpreting Article 111 as vesting in the federal government the power to translate an admirable constitutional principle into day-to-day application, not only is such an unattractive and potentially destructive situation avoided, but Article 111 is read in a manner that comports with the meaning of the Constitution's other relevant provisions.

\section{Conclusion}

The notion that Articles 110, 111, 112, 114 and 115 of the Iraqi Constitution all support the view that the Iraqi federal government alone is vested with authority to strike oil development agreements with international oil and gas companies is entirely consistent with the Constitution's expressions regarding the centrality of a unified and cohesive nation state. In the event governmental units other than at the federal level were seen as vested with the power to enter into oil development agreements, centrifugal forces impelling Iraqi ethnic and religious groups towards separation and eventual national disintegration would be unleashed. Such would prove entirely contrary to the pre-eminent value of Iraq as 'a single federal, independent and fully sovereign state', as expressed in the Constitution's Article $1,{ }^{27}$ and to the charge in Article 109 that the 'federal authorities shall preserve the unity' of the nation and its federal democratic system. ${ }^{28}$ The Constitution's expression of both these concepts underpins the position that the other relevant provisions of that document are best construed as providing only the federal government with the authority to consummate development agreements related to the nation's oil resources.

In the end, the complexity of the political, security and social problems faced by Iraq make it next to impossible to forecast with any degree of certainty what the precise outcome is likely to be over the intensifying struggle between federal

27 See Iraqi Constitution, n 5 above, at Art 1. Italics added.

28 See ibid at Art 109. Italics added. 
and sub-central governmental authorities regarding oil. Entrenched suspicions and power rivalries have clearly complicated and impeded the potential for the adoption of national legislation on oil and gas matters. There is little reason to believe that a complete reversal on that front will occur anytime soon; and this despite both expressions of dissatisfaction from, and the exertion of political pressure by, officials in the United States and other countries allied with Iraq. The obvious advantage of national legislation, regardless of how it finally addresses the issue of whether sub-central units will be acknowledged as having legal power to negotiate oil development agreements, is that its adoption will come at the cost of those in and outside Baghdad taking on a stake in the legislation's long-term success. In the absence of a national hydrocarbons law, however, any attempt to evaluate the propriety of claims to legal authority to enter into oil development agreements must turn on reference to the provisions of the Iraqi Constitution. Though not speaking explicitly to that matter, the relevant provisions of the Constitution can certainly be construed as assigning to the federal government alone the power to strike such agreements. ${ }^{29}$

29 On efforts to further strengthen the Constitution, and especially Arts 111 and 112, on the power of the federal government when it comes to oil, see Christopher M Blanchard, CRS Report for Congress - Iraq: Oil and Gas Legislation, Revenue Sharing, and US Policy at 9-10 (updated 25 July 2007) (Congressional Research Service Order Code RL.34064). 